\title{
The Palimpsestuous Face of the Other: Homoerotic Memory in Alan Hollinghurst's THE STRANGER'S CHILD
}

\begin{abstract}
This paper contends that Alan Hollinghurst's The Stranger's Child (2011) revises Sarah Dillon's renegotiation of De Quincey's "palimpsest" and Emmanuel Lévinas's "Face of the Other" to deal with the working of (homoerotic) memory. In joining the palimpsest and the Face of the Other as metaphors of the invocation and resurrection of Cecil Valance - the hero and tutelary spirit of the novel - I argue that the politics of remembrance and representation in The Stranger's Child shift, and change us as readers as well. From being a closeted gay WWI poet to becoming an early-twenty-first-century relic, Valance works as a "palimpsestuous face" that returns our gaze and forces us to renegotiate our relation with the past and the Other.
\end{abstract}

Keywords

Hollinghurst; palimpsest; the Other; palimpsestuous "face"; memory

\section{Introduction: The palimpsest and the face of the Other}

The poster of the exhibition "Faces of Conflict", held at the Royal Albert Memorial Museum \& Art Gallery of Exeter in 2014, featured a painting by René Apallec called Gueule Cassée No 138. It is a paper collage portraying what looks like a WWI officer. Yet, in line with the politics of the exhibition, the portrait is made up of fragments of different faces, as if they had been stitched together by a plastic surgeon. Likewise, as shown on the University of Exeter webpage (2015), Paddy Hartley's poster for the exhibition "Faces of Battle" at the National Army Museum features a face split into four, portraying the sur-face and the sub-face 
of WWI soldiers' faces. Both artistic manifestations draw on current revisions of memory and the articulation of identity when both memory and identity are in crisis. This cyborg-like retrochic imagery, ${ }^{1}$ whereby dead faces are stitched into one another to make up a new one, connects past and present very effectively. Moreover, it recalls the working of the palimpsest, which is the central motif of this paper.

A palimpsest is, according to the OED, "a parchment or other writing material written upon twice, the original writing having been erased or rubbed out to make place for the second; a manuscript in which a later writing is written over an effaced earlier writing". New layers are not only superimposed on those underneath, but also interrelated in "multi-linearity, nodes, links and networks" (Chicago School Media Theory, n.d.: par. 7). Likewise, the fragments of skin in the pictures above are interwoven as fabrics are in a palimpsestuous fashion. In this sense, I will refer to the palimpestuous palimpsest, as proposed by Sarah Dillon in "Reinscribing De Quincey's Palimpsest: The Significance of the Palimpsest in Contemporary Literary and Cultural Studies" (2005) and The Palimpsest (2007), as well as to Max Silverman's palimpsestic memory. Drawing on Dillon's revision of De Quincey's palimpsest, Brecht De Groote opts for a dual perspective that bridges the gap between the palimpsestuous as "primary, literary, figurative and metaphorical", and palimpsestic as "secondary, derived from critical selfreflection, literal and material" (2014: 127). Both the palimpsestuous and the palimpsestic are ways of remembrance, though. By contrast, critics like Lene Johannessen argue that the palimpsest puts forward the irretrievable character of memory, its erasures being lost "no matter how deep you dig" (2012: 898). This paper defends that the palimpsestuous iconography of Apallec's and Hartley's pictures and the articles of Dillon, De Groote and Silverman apply to and help understand Alan Hollinghurst's The Stranger's Child (2011).

The novel starts with Cecil Valance's visit to "Two Acres", the country house of his Cambridge friend George Sawle. There Valance flirts with George's sister Daphne and writes a poem (also called "Two Acres") allegedly dedicated to her. After the visit, the Arcadian motif is eclipsed, the war breaks out, and Cecil dies, becoming a WWI hero after the fashion of Rupert Brooke. Yet, Cecil, his pre-war visit and poem recur over and over again as a leitmotif; the first textual layer, a sort of prelapsarian time, the primeval "face" of the poet as a cultural artefact. Despite the passing of time, Cecil's "face" (more an idea(l) than an actual face) is stitched with those of WWI survivors as long as they publish memoirs focusing on his persona. Thus, unlike professional biographers like Stokes and Revel, who are concerned with Valance as text, Daphne, George and Dudley invoke him as a prosopopoeia. ${ }^{2}$ Likewise, in De Quincey's "The palimpsest", there is an insistence on "regaining the memory of Elizabeth's face ... [since it] is the very essence of his attempts for a palimpsestuous palimpsest constituted as an involuted circuit de sens" (De Groote 2014: 120). The involuted character of the "face" prompts remembrance through endless reflections that operate at surface level. Hence, I am using it as a metaphor that relies on and rejects the idea of an "abso- 
lute origin" (124). My approach to the "face" also recalls Lévinas, as "being neither something real inside, nor something ideal outside the world; [it] announces the corporeal absence (leibhaftige Abwesenheit) of the other". ${ }^{3}$ In other words, what I call Cecil's "face" is tantamount to our encounter with the text as Other. With the Other this article does not refer to the character's physical face, which is effaced every time it is described. Instead, it makes reference to the trace of the face as the signifier of a lost era and its claim to transcendence. The "face", for Lévinas, "is not literal or empirical but rather interrupts the ontological relation" (qtd. in Young 2015: 107). In Hollinghurst's novel the metaphor for this interruption is how Cecil's visit, his kiss to Daphne and Geroge Sawle, the subsequent poem and his memory are recast so often that it becomes difficult to discriminate between past, actual facts and apocrypha. The Stranger's Child thus reads and is structured in layers/generations that (like the fragments of faces in Apallec's and Hartley's compositions and Cecil's multifarious (ef)facing faces) complement and conflict with each other. Hence, the palimpsest - which I relate to Lévinas's "the face of the Other" - is a site of encounter and fractured memory under constant revision. Lévinas points to a change of direction, "de l'autonomie du sujet vers l'hétéronomie de l'assujettisement au visage de l'autre" (1982: 90). ${ }^{4}$ In this light, the "face" that Cecil's memory is made to embody would cancel out his survivors' and the new generations' autonomy owing to their subject-ion to him as their Other. This "assujettisement" to the other's face is akin to the working of the palimpsest; no text is autonomous. It only comes into being when interpellated by the other. However, for Lévinas, the Other is "not reduced to somebody or something in the world" (in Critchley 2002: 65), which would prevent Cecil from being the Levinasian Other stricto sensu. Moreover, it is problematic to automatically apply Levinasian asymmetry between the Same and the Other; the former being passively submitted to the latter. In this sense, I propose a strategic use of Lévinas's concept of "the face of the Other"; one that fits the rules of close reading and literary criticism, that reconnects with the ontological that Lévinas discarded in favour of a purely ethical relationality. Cecil's "face" would thus primarily be a textual phenomenon which makes characters and readers confront the Other as a myth of origins that renders them human. In this sense, characters and readers look at Cecil's "face" face-to-face -his life, words, physical appearance and even his tomb being recalled over and over again- somehow questioning Lévinas's conception that "the human is not the measure" (Cohen 2001:316).

\section{The Stranger's Child: Cecil's palimpsestuous face as an act of remembrance}

The Stranger's Child is split in five parts which span a whole century: from Cecil Valance's visit to "Two Acres" in 1913 to a twenty-page coda set in London's queer academic circles in the early-twenty-first century. Despite being a WWI victim, Cecil remains the tutelary spirit of the whole text. It is the fictional poet, 
and especially the way in which he is memorialised, that matters and makes up the layered text The Stranger's Child constitutes. The novel aims to be the re-construction of a myth of origins yearning for a prelapsarian Arcadia. As the novel progressively reveals, Cecil's Arcadia proves to be an intertextual fantasy recast by his generation and ensuing generations to come to terms with the(ir) trauma of loss. Whether Cecil's survivors and the subsequent generations work out or act out a primordial loss through their epiphanic encounter with his "face" is dubious and problematic. ${ }^{5}$ The second section of The Stranger's Child may shed some light on it, though. It is 1926 and Sebastian Stokes is visiting Daphne, her husband Dudley Valance, Cecil's brother, and their family to collect information to write a biography on the poet, which will eventually turn out to be a hagiography. Thus starts the process of palimpsestuous sedimentation and displacement of textual traces and memories that make up Cecil's "face".

All of Hollinghurst's novels are self-consciously intertextual. The Stranger's Child is no exception, Brideshead Revisited being one of its most obvious and extended hypotexts. However, rather than its intertextuality, it is the novel's palimpsestuous trans-textuality that this paper addresses. It makes a self-contained intertextual text that refers to itself even when it alludes to other texts. Like the strata in palimpsests, the novel casts Cecil's liminal persona in the form of others' words, impressions and readings within and outside the novel. Although there was a (Cecil's) bodily referent behind the textual fibre, as Critchley points out: "The Logos does not become flesh, it becomes face" (2002: 68). In other words, as a transreferential signifier, the protagonist's sexualised body is defactualised behind the folds of language, or palimpsests, used by other characters to address him when alive and recall, celebrate, or demythologise him when a haunting spectre. Further, in some cases, there lingers a homoerotic attraction to the memory of Valance.

Memory in The Stranger's Child is originally lived experience. However, it progressively moves into something without a referent, too displaced from itself under palimpsestuous strata to be rendered unambiguously. Memory is carved as a sculpture and, hence, Cecil's "face" is charming in the first section of the novel to become a heroic text and a marble sculpture in the second. Next, he is respectively contested, re-valued and queered in the following sections. ${ }^{6}$ That is the onion-like pattern the novel both makes up and deconstructs, drawing on Baudrillard's precession of simulacra. There is a move with respect to Baudriallard, though. The fact that Hollinghurst's novel puts forward how Cecil's "face" is multifariously devised depending on time and circumstances implies there is a "truth" somewhere in between the make-believe and the tangible presence of Valance prior to his death. Perhaps Cecil's persona and story are as varied as characters recalling him in biographies and memoirs. This is, in my view, one of the main features of the novel: instead of deconstructing the past, memory approaches us to it "face to face", updating Lévinas. This is rather ambitious of Hollinghurst because it implies making the novel contain a memory of its own to be recalled, rewritten, and effaced. Sebastian Stokes's hagiography turns Cecil 
into a hero when the trauma of war compelled the country to initiate new myths of origin. Thus, Stokes puts Cecil high above his readers and admirers who, in consequence, cannot look at the "face" of the heroic Other. For years both Cecil and his poem symbolise Britishness. Only surreptitiously do Daphne and George know and feel burdened by a flawed myth. The poem was addressed, we eventually learn, to George rather than to Daphne. And the latter was only infatuated by Cecil because she was too young. In the third and (especially) the fourth sections Paul Bryant, an ex-bank clerk working for Daphne's son-in-law, starts to pry into Cecil's secrets from the late 1960s onwards. Bryant does so because he aims to write yet a new biography on the WWI icon. However, unlike Stokes, the new biographer looks for traces of Cecil's homosexuality to read his texts and persona from a prejudiced perspective. (Sexual) politics meets literature. It is the time of gay and queer criticism, which coincides with the last section of the novel. Being Bryant a gay, he outs Cecil as an icon of the gay liberation movement he upholds. The ethical implications of Bryant's violent re-appropriation of tropes that carved up and effaced an era and a way of understanding and experiencing homosexuality are obvious, almost moralistic, towards the end of the novel.

The Stranger's Child is a self-contained exercise of memorialisation. In my view, it fits Max Silverman's concept of palimpsestic memory, "a ceaseless process of straddling and superimposition of elements, and condensation and displacement of meaning [whereby] memory traces overlap, intersect and are transformed" (2013: 22). In other words, memory works as palimpsests do, thus replacing the classic linearity of time with a relational chronology. Cecil's physical presence (which soon effaces into a transgenerational absence) and idyll "Two Acres" adopt multifarious forms throughout time. Drawing on Lévinas, he is the "'being that appears, but remains absent' (1991: 181) [and that] originates from a sort of epiphany" (Critchley 2002: 67). That is, he and his textual trace are effaced by new readings/layers. However, he re-surfaces as a revenant now and again. Therefore, the palimpsest is not the original event, text or "face". It is the relation between the original, its erasure and its trace, as it is triggered by the superimposed text. This is connected with Dillon's re-appropriation of De Quincey's "involutedness" and its rapport with the working of the palimpsest. The latter, Dillon argues, "is an involuted phenomenon where otherwise unrelated texts are involved and entangled, intricately interwoven, interrupting and inhabiting each other" (2005: 245). Be it as it were, I contend that the palimpsest comprises two conceptions central to my reading of The Stranger's Child: the non-linear relationality between layers of signification/representation and the metaphor of (Christian) resurrection as metaphors to verge on Cecil's "face", its demise and return.

Cecil's famous poem "Two Acres" reads:

Within that thronging singing woodland round

Two blessed acres of English ground,

$[\ldots]$ 
We'll walk the secret long dark wild dark path of love

Whose secrets none shall ever hear

Twixt set of sun late last rook and Chaunticleer.

Love as vital as the spring

And secret as - XXX (something!)

Hearty, lusty, true and bold,

Yet shy to have its honour told. (Hollinghurst 2011: 52, my italics)

Cecil is a sort of pagan God (69) for whom, Elspeth humorously remarks, George feels "a touch of hero worship" (62). As recalled by Tennyson (also a hypotext of The Stranger's Child) and other British poets, the link with pagan idylls in Roman and Greek Arcadian literature is patent. However, it is the echoes of E. M. Forster's Maurice (1913) and Evelyn Waugh's Brideshead Revisited (1945) that are the more hauntingly present. Cecil and George re-create the homoerotic scenarios of both hypotexts, namely the 'greenwood' Forster's characters roam in and Waugh's pre-war Arcadia. A minor character of The Stranger's Child argues that George "is very attached to [Cecil ...] in the Cambridge way" (62), their emotional engagement remaining a secret for years. It is precisely the absence implicit in secrecy that makes up the palimpsest in the novel: the relation between the said and the closeted, presence and absence is palimpsestuous and is, in the end, what matters about Cecil's prelapsarian persona and the way it haunts and is recast henceforth. Like Forster's Maurice and Clive, and Waugh's Sebastian and Charles, Cecil and George make up a romantic bond in an Arcadian fashion; one that draws on Plato and traverses Western history through poetry and its supporting homosocial tradition. Their bond is tightly interwoven, for it relies "on a favourite ... theme for both of them, their little myth of origins" (72).

When Cecil dies, the myth is fulfilled. In Tennyson's elegy "In Memoriam" the lyrical voice addresses his dead beloved Arthur Hallam. In The Stranger's Child, Cecil sees how the world he embodies fades away; nothing surprising though, since, as a friend of the family points out: "Cecil was awfully fond of Cecil" (173). In a sense, he dissociates from himself as he splits into both the lyrical voice and its addressee. He foregrounds his own early death and the mourning and mythology on the traumatic event. However, his death constitutes his resurrection as layers superimpose and are palimpsestously interwoven with each other: as a palimpsestuous palimpsest, Cecil's "face" returns or is summoned up in his survivors' memoirs and transhistorical transmission. His post-mortem return leads to the resurrective motif mentioned above. In fact, resurrecting is like being interwoven with the Other. Hence, the idea of the text as something woven "corresponds to the figuration of the palimpsest as a surface phenomenon in which two or more texts are inextricably entangled and intertwined" (Dillon 2007: 82-83). Related to this, I regard the "face" as a surface metaphor that, besides Lévinas, links to Kristeva's phenotext, "the surface phenomenon of a text present before us" (in Johnson 1988: 74) and engendered by the geno-text. ${ }^{7}$ The Stranger's Child (and Cecil in particular) constitutes a pheno-text that results 
from the many possible geno-texts or attempts to recall Cecil and his visit to "Two Acres" throughout the novel. In this sense, Cecil is made up of what (he) was not or what is (not) remembered. His absence (i.e. his absent or discarded geno-texts) defines him, particularly his trace and the way in which it is uttered.

\subsection{The encounter with the palimpsestuous Other as a resurrection fantasy}

The fantasy of resuscitating Cecil echoes Dillon's reading of De Quincey's grief for his sister Elizabeth's death and, more indirectly, Lévinas's "ethics of the Other". De Quincey devises the "palimpsest of the mind" as a "resurrective fantasy, as well as the uncanny type of "living on"" (Dillon 2005: 245) to secure his sister's spectral reappearance. If De Quincey's writing "performs the resurrection of Elizabeth" (246), Cecil's (and its subsequent revisions) performs his own, which leads to the romantic notion of the splitting subject. The latter is here related to the problematic utterance of the self and its rapport to the other in trauma cases. De Quincey rejects the very idea of "mourn[ing] his sister's death "normally" creating "a crypt in his mind that shelters [her]" (250). In Hollinghurst's text, the resurrective fantasy is doubly split. Cecil kisses George in Arcadia (2011: 84), but kisses his sister Daphne as well (94). Hence, Cecil's self-splitting in the text is projected onto his rapport to both brother and sister. Before dying, Cecil kisses George and Daphne and at that moment they are marked. It is as if the epiphanic moment the three experienced had become a crypt in the survivors' minds; or, as if Cecil had transmitted with his kiss his own loss which George and Daphne fail to introject (Abraham and Torok 1994: 14). The way Cecil splits into brother and sister draws on Forster's and Waugh's hypotexts, and well back into English literary tradition. In Forster's Maurice, Clive feels attached to Maurice and his sister Ada (Orrells 2011: 232) because her voice reminds Clive of Maurice, which constitutes "a compromise between memory and desire" (Singh, 1986: 167). Clive's interest vanishes "as his relation with Maurice comes to an end" (Villar 2005: 170) because Ada is a palimpsest of her brother. Likewise, in Brideshead Revisit$e d$, Charles displaces his attachment to Sebastian by eventually marrying his sister. In all cases brother and sister are exceptionally similar, a metaphor of their interchangeability and mutual ef-face-ment. However, the sister is just a displaced version (a second-best) of the brother who thus turns into the "original" layer of the palimpsest. Drawing on De Quincey's Elizabeth, sisters in Forster, Waugh and Hollinghurst act out the trauma of gay unutterability by becoming haunting corpses, dead or alive. When Cecil meets Daphne for the first time, she does not wear "her own dull coat, but ... one of George's old tweed jackets" (Hollinghurst 2011: 89). Covered with George's jacket, Daphne IS George. They mirror and are interwoven with each other (fighting for Cecil's attention) as palimpsestuous layers do. The same happens with the poem. Arguably destined to Daphne, it is, George states, written for him (194). "Two Acres" thus becomes the poet's resurrective fantasy. Once he is dead, it is doubly embodied in brother and sister, being encrypted in their minds and in those of future memoirists and readers. 
Drawing on the metaphoric palimpsest of the mind, Dillon contends that the endless strata "are ever ready for revival and resurrection" (2007: 28). Whereas De Quincey's writing performs the resurrection of Elizabeth, biographers do so with Cecil in The Stranger's Child. However, while Elizabeth's return is an intimate event, Cecil's has a cultural effect that draws on Christological iconography. As years pass, survivors reject the prospect of mourning and introjecting Cecil's loss, and a cryptic version of the dead poet is incorporated in his family and friends' unconsciouss instead. The spectral presence of his trace is ubiquitous. In fact, the transgenerational migration of the ancestor goes through his progeny. As a child, Daphne's son Wilfie was "haunted and puzzled by phantom uncles. Uncle Cecil was in the house, in a highly idealised marmoreal form, and was often invoked" (Hollinghurst 2011: 135). Lady Valance, Cecil's mother, summons the phantom of her son, an event that biographers like Sebatian Stokes confirm. George's encounter with the effigy Lady Valance raises as a memorial is ironic to say the least. The solemnity of the scenario clashes with the clandestine sexual encounters George had in Cambridge with the acclaimed soldier-poet (150-152). Still with a glance back over his shoulder George faces Cecil's white figure that effaces Cecil's "actual" face, for it is encrypted in George's memory. The dead's marble figure "stretched out flat ... seeming to float above the floor. ... It was as if the chapel had been built for him" (152). The heroic, quasi-religious iconography of the chapel grants him an aura that both confirms and rebuts George's memories (153-154). Cecil's imagery, George concedes, is surely based on its many photographs and descriptions, and yet, he mumbles: "All these depictions were in a sense failures, just as this resplandescent effigy was" (154). Cecil, like the novel as a whole, works as a palimpsestuous palimpsest: his effigy and the biography by Sebastian Stokes make up the resulting pheno-text from the "infinite possibilities" (Dillon 2007: 87) of geno-texts (in the form of images, memories and photographs) which could have been (chosen). As the novel advances, Cecil's "face" adopts multifarious forms through whose encounter most of the characters make up their own selves and confront their own crises. Yet, his memory is determined by the cryptic incorporation that George and others perpetuate in their refusal or impossibility to mourn him. The novel is the effect of the melancholia enacted whenever the remaining characters fail to introject Cecil's interpellation from the other side.

Although the kernel of Cecil's resurrection fantasy coincides with the first part of the novel, it is its palimpsestuous re-appraisal in the subsequent layers/sections of The Stranger's Child that matters. Dillon devotes part of her monograph on the palimpsest to analyse the phenomenon in detective fiction (2007: 63-68, 76-82). In fact, the genre excavates layers and possible truths to reach the "Truth" in a way that recalls the working of the palimpsest. Likewise, biographers such as Stokes dig into memorabilia to produce an integrated whole which fits the conventions of writing biographies. In fact, the whole second part of the novel virtually draws on the features of detective fiction, Stokes gathering the whole family to invoke Cecil's memory and bring him back to life. Not by chance is Stokes 
referred to "as a clever Monsieur Poirot" (Hollinghurst 2011: 174) in the session. The continuous processes of resurrection Cecil's memory undergoes along the novel clash with the poetics of unutterability his "true" identity demands. George is particularly haunted by "an unmentionable truth" (150), "a secret ... that could never be told ... unpublished, unpublishable" (159).

With this in mind, I will deal with the "homosexualisation" of Cecil as a palimpsest in the next point. The rest of the second section continues addressing unsayable, palimpsestuously-related secrets, namely the letters between Cecil and George -which Daphne agrees to hide (186-187) - and Revel's own sexual attraction to Cecil (197). The section is both the first act of Cecil's resuscitation and the proof of his palimpsestuous re-creation: the fragments of his "face" and its multiple geno-texts make up the first draft of a polymorphous palimpsest his survivors start to utter prompted by his biographer and admirer. De Quincey, Dillon points out, draws off the cloth spread over his sister's coffin (2007: 28). Likewise, whenever any of the biographies of the characters in the novel - George's (Hollinghurst 2011: 363), Daphne's (306, 313, 374), Dudley Valance's (388), Stokes's or Paul's - recall Cecil, the cloth over his "face" is ef-faced and its fabrics are partially unwoven. And thus Cecil's loss passes from being incorporated to being introjected (Abraham and Torok 1994: 14). De Quincey's words are worth noting once more: "The tyranny of the human face began to unfold itself ... The human face began to reveal itself; the sea appeared paved with innumerable faces ... faces, imploring, wrathful, despairing; faces that surged upwards by thousands, by myriads, by generations" (Dillon 2005: 64). Similarly, Cecil's "face" unfolds as soon as he dies. Henceforth, his disencryptation and subsequent resurrection commence. In his tomb, the narrator points out, Cecil seemed to be "in some floating cortege of knights and nobles reaching back through the centuries to the crusades" (Hollinghurst 2011: 153). He is haunted by other spectres in the way in which he haunts his survivors. Once dead, Cecil is not the Same, but the Other, an other that interpellates and is palimpsestously re-created by the rest of the characters; or so it seems. In fact, Cecil's "face" is elusive because, as Other (although for Lévinas, the Other is no concrete subject (Critchley 2002: 65)), he cannot be spoken to directly. However, although the novel plays with the impossibility of life-writing in classical terms, it still yearns for the romantic idea of the self as an integrated whole, even if made up of stitched fragments.

\subsection{Homosexualising Cecil's palimpsestuous face. Palimpsesting memory in search of the elusive Other}

The third section of the novel, "Steady, Boys, Steady" introduces Paul Bryant. Firstly a bank clerk, he eventually devotes his life to uncover and resuscitate the 'real' Cecil as if he was an inquisitive detective in the name of gay politics. Under constant revision along the twentieth century, the poet is considered "awfully imperialist" (Hollinghurst 2011: 263) by Daphne's grand-daughter Jenny in the late sixties, or simply second-rate (349) later. The logic of fashion is 
unpredictable. After being worshipped as a national icon in the twenties and derided for the same reason in the sixties, he is re-appropriated after the liberation movements. Yet, re-turns are often de-tours because the original can no longer be read ex nihilo, but rather as the effect of the interaction between layers of representation, present and past. Cecil's "face" returns our gaze and everything is transformed. With the coming of the gay liberation movement, the ambiguous poet arouses a new fascination. And Paul Bryant is to herald Cecil's definitive queering process to such extent that the poet is made into a password for gayness (340-347). The poetics of unutterability mentioned above implies there is an identity politics whereby some identities cannot be spoken. Bryant's detective search for homosexual traces responds to a gay identity politics which nuances the anti-ontological discourse of Lévinas and the deconstructive one of Dillon's palimpsestuous reading. For Paul, the password effaces and exposes the gay man behind. Hence, for the gay community that Paul represents, Cecil's coming-out is possible 'thanks to' the Sexual Offences Law passed in 1967 (320). However, George's wife addresses the ethical side-effects of the compulsory coming-out of closeted celebrities (320). For the new generation of gays it is just a proof of political change that allows buried crypts to be finally exorcised and introjected. Yet, this politics whereby the text hides a 'truth' inside somehow simplifies Dillon's view. If in a palimpsest "one text is not derived from the other" (2005: 85) but in the form of a non-linear node, link, or network, Bryant's identification between Cecil's texts and his sexuality is simplistic to say the least. In this sense the novel is very critical of Bryant's ethically dubious procedure and conclusions, making him into a ludicrous character (522-523).

Max Silverman starts his poetics of memory with three different scenarios where layers representing extreme violence are superimposed revealing one another. In the first case, on François Emmanuel's La Question Humaine, the narrator has "a feeling of 'doubling' and [finds him]self hesitating over words whose meaning had suddenly become strange; it appeared ... that the first technical text had been invaded and as if devoured by the other text" (Silverman 2013: 1). Also Didier Daeninckx' Meurtres pour mémoire and Leïla Sebar's La Seine était rouge layer traces of violent moments in history "producing a dense condensation of meaning" (2). Silverman's palimpsestuous conception of memory - much like that of Rothberg's "multidirectional memory" (2009) - relies on a composite structure (3). In the novels mentioned above such structure "is a combination of not simply two moments in time (past and present) but a number of different moments, hence producing a chain of signification which draws together disparate spaces and times" (Silverman 3). The fact that different texts and different inscriptions are connected to explain each other gives way to a different spatio-temporal configuration that traverses and dismantles classic historiography. Although Hollinghurst's novel does not draw on the transformative process of palimpsesting violent moments, it relies on Silverman's memory poetics. Parallel to Paul Bryant's archaeological work to excavate the different Cecil(s), the latter's house at Corley Court undergoes a similar metamorphosis as if new layers 
fell over the original. From being the Valances' idealised household in part one, and the shrine of Cecil's tomb in part two, it turns "a Victorian monstrosity" (Hollinghurst 2011: 268) in the third. The building is refurbished into a boarding school for boys, where the only redeeming feature from Cecil's home happens to be his white marble tomb (269). The tomb is no longer a holy site for students, who "fix pretend cigarettes between the poet's marble lips ... and carve initials on the side of the chest" (349). Being an act of vandalism, it also puts forward how the palimpsestous character of the novel finds a metaphoric layering of space and time. Thus the "faces" of the house and its old lodger are rearranged and forced to "come out" once and again. Likewise, Daphne goes through a whole metamorphic process that galvanises Cecil's changing reception: from being a naive girl infatuated with her brother's friend and a Jamesian focaliser, she becomes an old lady who utters her demythologising truth about Cecil and their alleged Arcadia. The novel renders this overall transformation by making Daphne assume different names as she marries different men, thus being successively Mrs Valence, Mrs Ralph and Mrs Jacobs. Being chameleonic, she is just an element in memory that works as "a hybrid and dynamic process across individuals and communities" (Silverman 2013: 6).

Rather than abiding by a "linear, syntagmatic and teleological axis", The Stranger's Child abides by "a vertical paradigmatic axis of dialectic thinking so that events are 'piled up' one on the other rather than ordered in a chain" (Silverman 2013: 27). Cecil's reception is a good metaphor of this fact. His actual exorcism (or rather exhumation) takes place in the last two sections. In front of the Letters of Cecil Valance edited by George, Paul "looked down at Cecil's face, the dark prominent eyes" (Hollinghurst 2011: 379) as if resurrecting the poet. The exchange between observer and observed seems epiphanic, though it is only the preface to Paul's encounter with Cecil's "face". This is a complex process that involves all traces left by Cecil behind and that render him a readable crossreferential palimpsest. Even "Two Acres", mythologised in Cecil's epomymous poem, is deconstructed to its essentials, namely the red bricks of a late-Victorian house recently refurbished into Six Executive Homes (382-384). Like the pages of a book or the impression of an interpellating face, stones are only superficially effaced to reveal others. "The Cecil job", as Paul calls his detective-like resurrection of the poet, proves problematic because his gay-biased reading of Cecil manipulates contradictory traces and closeting testimonies, which he arranges like interwoven fabrics in Dillon's metaphor. In view of the biographies, autobiographies, memoirs and letters Paul comes across, the so-called reality seems particularly precarious, misleading and elusive (398). He tries to find out traces of sexual acts between Cecil and George, and between Cecil and his valet Jonah in some recordings and texts, though to no avail. Geno-texts and versions are too many and too difficult to unravel. However, Paul and his queer-hunter Jake do not stop outing closeted homosexuals. In this respect, their exchange on new material on the poet is really telling: 
So he was gay too, was he?

Again ... among other things.

Again Jake was delighted. They all were, weren't they? [Jack] said.

Paul felt he should be a bit more cautious: I mean, he did have affairs with women, but I have the feeling he really preferred boys. That's one of the things I want to find out. (420)

Paul's intrusive act only reminds Lévinas's censorious position towards literary criticism. On interpreting meaning and analysing form, literary criticism "is inscribed for Lévinas as ontological" because it attributes "meaning or ... appl[ies] a method to a work of art attempt[ing] to speak for the Other" (Young 2015: 110-111). Thus, Paul's act of outing Cecil to interpret his writing is not only dubious from a moral viewpoint, but also from the perspective of Levinasian ethic. In his zeal to discover the "Truth", he maps Cecil's traces writing down in a diary his conversation with George and Daphne. Paul attributes meaning to the Other to confirm his own (gay) premises. Hence, although George denies most of Paul's hypotheses, the latter's prejudiced discourse is inscribed (in Lévinas's terms) in the constative and ontological, rather than in the ethical. In other words, Paul does not speak with (but for) Cecil. Paul's last attempt to confirm his theory on the homosexual affair between Cecil and George leads him to Daphne. Once again Bryant sees his expectations unfulfilled. The old lady corroborates the unusual relationship between her brother and his friend not as a sexual one, but as the classic "hero-worship" (Hollinghurst 2011: 479). Yet, the classic hero-worship that went on in Cambridge in those days was often the kind of cover-up for congresses of a more carnal nature. The clash between versions of so-called reality lays bare the working of a palimpsestuous event like the Arcadian "Two Acres" that hides a sexualised underside. Against Paul's expectations, Daphne reduces the myth and its aureatic "face" to a minor event in her memory: "The thing is, they all get it wrong .... Really Cecil means nothing to me - I was potty about him for five minutes sixty years ago" (490). In the end, it is Daphne who makes clear how (Cecil's) palimpsest works: "Memories [a]re only memories of memories" (496). This is the fabric of which memory and the "face" of the Other are made in The Stranger's Child: relational, precarious and elusive.

The last section is prefaced with a line from Tennyson's In Memoriam: "No one remembers you at all". Palimpsests work in unpredictable ways, swinging between remembrance and forgetfulness, death and resuscitation. This is the essence of the palimpsest of the mind and its connections. Rothberg's "Multidirectional memory" delves into the way memories interact with each other and thus help explain their functioning on a relational basis. This is what happens in The Stranger's Child, where memories of the different characters make reference to one another in a non-linear fashion. This standpoint develops poststructuralist concepts like Barthes's "polysemic space" (1981: 37) and furthers into Derrida's description of the text as "a differential network, a fabric of traces referring endlessly to something other than itself, to other differential traces" (1999: 84). However, what Hollinghurst's novel eventually addresses is the palimpsestuous read- 
ing of the palimpsest to articulate a homosexual biography. Twentieth-century feminism (and gay politics by proxy) considers "the structure of the palimpsest in terms of suppression and oppression, of layering and superimposition. The task ... is to uncover and bring to light the suppressed women's narratives concealed within these texts" (Dillon 2005: 256). For Dillon, the feminist and gay use of the palimpsest is reductionist as it ignores overlying texts and the complex relationality a palimpsestuous reading offers. There is no such thing as a truthful text to be exposed, but a reading process that "traces in the fabric of literary and cultural palimpsests the interlocking narratives of 'masculinity' and 'femininity', 'heterosexuality' and 'homosexuality' that characterize gender and sexual identity, writing and culture" (257). Dillon equates palimpsestic reading (related to Foucault's 'archaeology') with feminism and gayness, and palimpsestuous reading (akin to Foucault's 'genealogy') with queerness. And, in my view, she regards the second pair as more politically effective. Hollinghurst's novel questions her view. It opens palimpsestuousness to gay poetics and identity politics, dismantling the equation queer-progressive. That is, Hollinghurst sticks to a progressive agenda; yet one that vindicates essentialist gay politics rather than deconstructive queer theory.

Section five, "Old Companions", shows the current queer scene. It is 2008 when Paul, now a moderately popular second-rate writer, attends his ex-lover Peter's funeral. The funeral reflects the shift from gay to queer while both generations share the same space. Peter stands for the 1967 pro-gay law and the fight for same-sex civil partnerships (Hollinghurst 2011: 535). Likewise, Paul stands for the fashionable "outing of gay writers" (525) at the time. Finally, Rob and Raymond embody the new generation who has made Cecil into a gay icon (535) and, later, his poems into "a sort of queer manifesto" (541). However, rather than queer theory - related to Dupont's obscure verbosity - Rob and Raymond regard themselves as gay and, hence, represent a gay conception of the palimpsest. This conception combines the poetics of detective fiction and Foucauldian archaeology, whereby gays search for traces of gayness to establish a gay tradition, and the new ways for gays to address their ancestors thanks to new technologies. The effect is akin to Dillon's queer palimpsestuousness.

Like in classic detective novels, Rob and Raymond try to discover who the real Cecil was, not in the intrusive way that Bryant does, but rather by trying to open old texts to new interpretations. It is not their purpose to dig into the text to find out an "absolute origin", but to decode its involuted (gay) messages on the surface: "Jumping ahead, Rob started to see there was something else going on, a kind of shadow side to the glow of gratitude. June 4, 1913 - 'My dear old Harry'. ... I am not the demonstrative type, it is not in my nature" (553). The text was there before, but it reveals itself to Rob as a shadow side that changes the story. It seems that Cecil and Daphne's elder brother, Hubert, were both emotionally engaged to the industrialist Harry Hewitt. If memory works at random and traces sometimes reveal themselves in unprecedented ways changing the palimpsest and its "face", this is doubly so when past and present are overtly engaged. 
In this sense, Raymond's technological approach to literature proves to be very graphic. Drawing on "early séances" (549), Rob and Raymond are confronted with the face of the spectral Other using the most sophisticated technology. Transhistorical communication adopts new forms with surprising effects. Raymond shows Rob a digitalised video where Tennyson's face takes centre stage as he reads one of his poems:

Against a rainstorm of hissing ... the ... voice of the great poet began its familiar rush through 'Come into the Garden, Maud'. ... The bard's beard quivered like a beast in a hedge, as the famous face made repetitive mincing and chewing movements... Then it came to its abrupt end, and Raymond's copyright line -not in the recording or the image, but in the puppet-show he's made with them- appeared across Tennyson's frozen face." (550)

I am not addressing the "face" here in a specular fashion, although Hollinghurst does it very often. The face that the new generation of gays ascribes to their ancestors is particularly intricate. In Raymond's show (much in line with Helen Davies's "neo-Victorian ventriloquism", 2012) the spectre is not invoked, but made of light beams that interweave palimpsestuously and interpellate us. The act of remembrance whereby Tennyson is resuscitated constitutes an epiphanic moment of reconaissance of the dead other, which addresses gay genealogy. Yet, pace Lévinas, Hollinghurst's twenty-first-century characters do not remain passive in front of the Other. They actively engage with the Other's "face", showing their own. The final effect is a post-romantic "face" that, drawing on René Apallec and Paddy Hartley, integrates Cecil's "faces" as they have been experienced through memory and interpellation.

\section{Concluding remarks}

I am conscious this paper has opened more doors than it has closed. This is not necessarily a drawback, but rather constructive in a moment of shifting paradigms. Although the memory boom of previous decades has receded (Bell 2006), the revision of the palimpsest and Lévinas's "face of the Other" shed new light on how we relate to otherness and the past when they are more elusive (albeit more mandatory) than ever before. Drawing on Foucault's genealogy and Kristeva's geno-texts, Dillon's and De Groote's palimpsestuous reading proves to be an effective starting-point to approach the way Hollinghurst's novel opens the ethics and poetics of identity, memory and transcendence. From a post-postmodernist neo-romantic stand, The Stranger's Child revives identity and gayness to (among other reasons) sustain palimpsestuous connections transhistorically. Obviously, this claim to essentialism and transcendence is problematic. That is, the return to a re-integrated sense of selfhood is strategic. It proves necessary though; at least as a fictional device to address issues, particularly ethically-inflected ones, which were particularly difficult to deal with from post-structural (queer) relativism. 
Through the characters' acts of remembrance and forgetting, readers wonder whether "Truth" is to be found in the Folds between palimpsests; and whether a palimpsestuous reading is effective and ethical. Yet, it is especially the articulation of the "face" as a metaphor of the relation between the Same and the Other in a post-Levinasian context that best addresses the novel's palimpsestuous discourse. Cecil's "face" and all it represents is physical as far as it is textual. However, it transcends itself when it breaks into textual fragments the rest of the characters' memoirs gather to fabricate (Cecil's) Arcadia as opposed to their own otherness. The Stranger's Child thus proves to be a neo-romantic text that resurfaces the subject and recasts Lévinas's asymmetric relation between Same and Other into one of mutual understanding whereby Cecil is resurrected palimpsestuously.

\section{Notes}

1 For the origins of cyborg imagery, see Donna Haraway (2004: 7-46, 295-342); for the concept of the "retrochic", see Raphael Samuel (1994).

2 As a matter of fact, prosopopoeia implies "creating the face, specifically ... of the dead, absent ... person as alive, present and real" (De Groote, 2014: 211). The Greek etymology is very graphic. According to the Online Etymology Dictionary, prosopon means person or face, and hence, prosopopeia is "something which is toward the eye, person or face" of the other. From this literal translation comes the current idea of putting "the speeches into the mouths of others".

3 We may call it "the corporeal emblem of the other's otherness" (Bernhanrd Waldenfels qtd. in Critchley, 2002: 66).

4 "From the subject's autonomy to the heteronomy of the submission to the face of the other", my translation.

5 This surgical/textual intervention on selfhood, particularly that of queering the "face" (as Lévinas's ultimate metaphor), is also, as will be shown, a metaphor of Hollinghurst's novel and its poetics of transhistorical transmission.

6 Torsten Caeners points out that Seamus Heaney's poem 'Tollund' "expresses the palimpsestuousness nature of memory, the desire for pure recollection in the face of the impossibility of that desire" (2015: 299). The Stranger's Child addresses that (im)possibility by palimpsesting layers of representation and memory traces recalling the protagonist's "face" metaphorically.

Said otherwise, Dillon argues that "the geno-text corresponds to the infinite possibilities of palimpsestuous textuality, the phenotext to the 'singular trace' of the virtual entities that it could have been" (2007: 87).

\section{Acknowledgements}

The author would like to acknowledge the support of the Spanish Ministry of Economy, Industry and Competitiveness (MINECO) and the European Regional Development Fund (DGI/ERDF) (code FFI2017-84258-P), and the Government of Aragón and the European Social Fund (ESF) (code H03_17R), for the writing of this essay. 


\section{References}

Abraham, Nicolas and Maria Torok (1994) The Shell and the Kernel. Chicago: Chicago University Press.

Barthes, Roland (1981) Theory of the Text. In: Young, Robert (ed.) McLeod, Ian (trans.) Untying the Text. A Post-structuralist Reader. London: Routledge, 31-47.

Bell, Duncan (ed.) (2006) Memory, Trauma and World politics. Reflections on the Relationship between Past and Present. Houndmills: Palgrave Macmillan.

Caeners, Torsten (2015) Memory and Memory Work. In: Wolfreys, Julian (ed.) Introducing Criticism in the $21^{\text {st }}$ Century. Edinburgh: Edinburgh University Press, 282-307.

Cohen, Richard (2001) Ethics Exegesis and Philosophy: Interpretation of Lévinas. Cambridge: Cambridge University Press.

Critchley, Simon (ed.) (2002) The Cambridge Companion to Lévinas. Cambridge: Cambridge University Press.

Davies, Helen (2012) Gender and Ventriloquism in Victorian and Neo-Victorian Fiction. London: Palgrave.

De Groote, Brecht (2014) The Palimpsest as a Double Structure of Memory. Orbis Literarum 69 (2), 108-133.

De Quincey, Thomas (1995) Confessions of an English Opium Eater. New York: Dover Publications.

Derrida, Jacques (1999) Living on: Border Lines. In: Bloom, Harold (ed.) Hulbert J. (trans.) Deconstruction and Criticism. New York: Continuum, 75-176.

Dillon, Sara (2005) Reinscribing De Quincey's Palimpsest: The Significance of the Palimpsest in Contemporary Literary and Cultural Studies. Textual Practice 19 (3), 243-263.

Dillon, Sara (2007) The Palimpsest. London: Bloomsbury.

Forster, E. M. (1971) Maurice. London: Penguin Classics.

Haraway, Donna (2004) The Haraway Reader. New York: Routledge.

Hollinghurst, Alan (2011) The Stranger's Child. London: Picador.

Johannessen, Lene (2012) Palimpsest and hybridity in postcolonial writing. In: Quayson, Ato (ed.) The Cambridge History of Postcolonial Writing, volume II. Cambridge: Cambridge University Press, 869-902.

Johnson, Christopher M. (1988) Intertextuality and the Psychic Model. Paragraph 2, 71-89.

Lévinas, Emmanuel (1982) Ethique et Infini. Paris: L'espace Interieur.

Lévinas, Emmanuel (1991) Totality and Infinity. Dordrecht: Kluwer Academic Publishers.

Orrells, Daniel (2011) Classical Culture and Modern Masculinity. Oxford: Oxford University Press.

Rothberg, Michael (2009) Multidirectional Memory. Stanford: Stanford University Press.

Samuel, Raphael (1994) Theatres of Memory. Present in Contemporary Culture. London: Verso.

Silverman, Max (2013) Palimpsestic Memory. The Holocaust and Colonialism in French and Francophone Fiction and Film. New York and Oxford: Berghahn.

Singh, Avtar (1986) The Novels of E. M. Forster. New Delhi: Atlantic Publishers.

Tennyson, Alfred (1974) In Memoriam, Maud and other Poems. London: Dent.

The Chicago School of Media Theory (n.d.) Palimpsest. Accessed from https://lucian.uchicago. edu/blogs/mediatheory/keywords/palimpsest/ on 12 Nov. 2015.

University of Exeter (14 Jan. 2015) Exhibition reveals the impact of WW1 on art and facial reconstructive surgery. Accessed from http://www.exeter.ac.uk/news/research/title _429629_en.html on 17 Nov. 2015.

Villar, Carlos and Robert Murray Davis (2005) Waugh without End. Bern: Peter Lang.

Waugh, Evelyn (1988) Brideshead Revisited. London: Penguin.

Young, Frederick (2015) Lévinas and Criticism. In: Wolfreys, Julian (ed.) Introducing Criticism in the $21^{\text {st }}$ Century. Edinburgh: Edinburgh University Press, 101-121. 
José M. YeBRA is a lecturer in English at the University of Zaragoza. He has published widely on contemporary British and Irish literatures, particularly on Alan Hollinghurst, Colm Tóibín, Naomi Alderman and Will Self. His research trends include contemporary British literature, trauma theory, and gender and queer studies. His last articles have appeared in The Journal of Language, Literature and Culture, Anglia and Orbis Litterarum. He is a member of a research team and project on literatures in English headed by Dr. Susana Onega.

Address: José M. Yebra, Facultad de Ciencias Humanas y de la Educación, University of Zaragoza, Departamento Inglés, C/ Valentin Carderera, 4, 22003, Huesca, Spain. [email: jyebra@unizar.es] 